\title{
Rice straw: a valuable organic manure for soil amendment in the cultivation of groundnut (Arachis hypogaea)
}

\author{
Abdul'Aziz Ayinla*, Bolaji U. Olayinka, Emmanuel O. Etejere \\ University of Ilorin, Faculty of Life Science, Department of Plant Biology, P.M.B 1515, Ilorin, Nigeria \\ *Corresponding author, E-mail: ayinlaabdulaziz@gmail.com
}

\begin{abstract}
The study focused on evaluating the effect of ground and unground rice straw as soil amendment on growth, yield and post-harvest soil nutrient concentrations. The experimental layout was a split-plot design with ground and unground straw as the main plots and different application rates $\left(\mathrm{T}_{0}=\right.$ control; $\left.\mathrm{T}_{1}=1250 \mathrm{~kg} \mathrm{ha}^{-1}, \mathrm{~T}_{2}=2500 \mathrm{ha}^{-1}, \mathrm{~T}_{3}=3750 \mathrm{ha}^{-1}, \mathrm{~T}_{4}=5000 \mathrm{ha}^{-1}\right)$ as subplots. Rice straw at all application rates significantly increased all growth parameters when compared with the control. Application rates at 1250 and $2500 \mathrm{ha}^{-1}$ of both ground and unground rice straw favoured higher yield when compared to other application rates and the control. Post-harvest soil nutrient concentrations were also higher under these rates except for calcium, magnesium and molybdenum. The results suggest that the use of rice straw at lower application rates could be considered as optimum for groundnut production. Its use could also limit environmental pollution arising from burning of rice straw.
\end{abstract}

Key words: Arachis hypogaea, growth characteristics, rice straw, soil nutrients, yield attributes.

\section{Introduction}

The global production of rice straw is about 731 million tons annually while the production rates in Africa, Asia and Europe are 20.9, 667.6 and 3.9 million tonnes per hectare, respectively (Binod et al. 2010). Only $20 \%$ of the annual production is used for purposes, such as ethanol and paper production (El-Gamal et al. 2001), and the remaining $80 \%$ is left on the field for burning, which contributes to global warming (Lemieux et al. 2004) and atmospheric pollution (Keshktar et al. 2005). Attempts made to minimize burning of rice straw have involved the use of this waste to generate electricity, which amounted to 3.8 billion KWh annually in Japan (Yukihiko et al. 2005), composting livestock feed (Abdelhamid et al. 2005) and as mulch for weed control in groundnut fields (Olayinka, Etejere 2016).

Groundnut is cultivated on approximately 17 million hectares throughout the tropics and subtropical parts of the world (El-Naim et al. 2011). However, its high nutrient demand from the soil poses a problem for its cultivation (Veerahmani, Subrahmaniyan 2011). The use of inorganic fertilizer to augment the available soil nutrient in meeting groundnut demand has been well documented. This includes the application of 30:60:30 $\mathrm{kg} \mathrm{NPK} \mathrm{ha}^{-1}$ (Vinod et al. 2000), 34:64:108 $\mathrm{kg} \mathrm{NPK} \mathrm{ha}^{-1}$ (Chitdeshwari et al. 2003), 20:60:40 kg N, $\mathrm{P}_{2} \mathrm{O}_{5}, \mathrm{~K}_{2} \mathrm{O} \mathrm{ha}{ }^{-1}$ (Munda et al. 2004), 25:50:00 kg NPK ha-1 (Thorave, Dhonde 2007). All these application rates have been reported to enhance groundnut yield. The prolonged use of inorganic fertilizers, due to their accumulation have been found to cause soil degradation, nutrient imbalance and soil acidity (Basel, Sami 2014). Due to the above, the objective of this study was to find means to further minimize the burning of rice straw by demonstrating its utilization as a valuable soil amendment in the cultivation of groundnut. Its use will also provide the advantage of limiting the need for inorganic fertilizer.

\section{Materials and methods}

\section{Description of experimental field}

The experiment was conducted at the University of Ilorin Teaching and Research Farm, Ilorin located at $4^{\circ} 38.920^{\prime} \mathrm{E}$ to $4^{\circ} 39.971^{\prime} \mathrm{E}$ and $8^{\circ} 27.810^{\prime} \mathrm{N}$ to $8^{\circ} 28.230^{\prime} \mathrm{N}$. The dimension of the field, consisting of forty sub-plots, was $9.45 \times 24.5 \mathrm{~m}$. Each subplot was $2 \times 2 \mathrm{~m}$ consisting of four rows with an inter-row spacing of $0.1 \mathrm{~m}$.

\section{Experimental design and treatment details}

There were four treatment levels each of ground and unground rice straw. The field layout was a split plot design. The ground and unground rice straw were allotted to the main plots and the different application rates $\left(\mathrm{T}_{0}=\right.$ control; $\mathrm{T}_{1}=1250 \mathrm{~kg} \mathrm{ha}^{-1} ; \mathrm{T}_{2}=2500 \mathrm{~kg} \mathrm{ha}^{-1} ; \mathrm{T}_{3}=3750 \mathrm{~kg} \mathrm{ha}^{-1}$ and $\mathrm{T}_{4}=5000 \mathrm{~kg} \mathrm{ha}^{-1}$ ) to sub-plots. The application rates were arranged following a complete randomized block design with three replications in the main plot. The rice straw used for the study was collected in November, 2013 from a farm at Lafiagi in Kwara state. Ground rice straw was formed by milling half of the rice straw collected. The ground and unground rice straw were then applied as following 
different application rates as stated above by manually ploughing them in to the soil to a depth of $0.1 \mathrm{~m}$. The field was then watered to saturation point at an interval of three days for a period of two weeks to facilitate decomposition.

\section{Composition of rice straw}

Samples of rice straw used were analysed for both macro and micro nutrients. Total nitrogen concentration was determined by micro-Kjedhal method (Bremmer 1996). Total phosphorus concentration was determined by the ammonium molybdate/vanadate yellow colour method following ternary acid-perchloric-nitric-sulphuric acid wet digestion (Anderson, Ingram 1993).Total boron concentration was measured by azomethane-hydrogen method following ternary acid digestion (Jones 1991). Total cation concentrations (calcium, magnesium, copper, iron, manganese and zinc) were determined by atomic spectrophotometer. Elements such as sodium and potassium were analysed using flame photometry following a wet digestion with perchloric-sulphuric ternary acid (Anderson, Ingram 1993). Sulphur concentration was determined by turbidometry. Organic matter and ash content was measured using the method described by Okalebo et al. (2002). Organic carbon was determined by Walky-Black method as described by Nelson and Sommer (1982).

\section{Soil analysis}

Mechanical analysis of soil by the hydrometer method was conducted to determine particle size distribution. The $\mathrm{pH}$ of the soil sample was recorded by a $\mathrm{pH}$ meter with an electrode in a beaker; electrical conductivity was using a conductivity meter. Organic carbon concentration was determined using Walkley-Black method as detailed by Nelson and Sommer (1982). Organic matter and ash content using the method described by Nelson and Sommer (1982). Cation exchange capacity (CEC) was determined via ammonium saturation of exchange sites and estimation of saturated ammonium using an ammonium ion-selective electrode. Base saturation was determined as total bases / CEC $\times 100$ and reported in \% (Soil and Plant Analysis Council 2000). Soil calcium, magnessium, potassium, and sodium were determined via Inductively Coupled Plasma Spectrophotometry.

\section{Field operation}

Groundnut seeds (MK 373) were obtained from the College of Agriculture Mokwa, Niger State of Nigeria. Seeds were treated with $500 \mathrm{mg} \mathrm{kg}^{-1}$ dress Force ${ }^{\varpi} 42$ w containing $20 \%$ imidacloprid, $20 \%$ metalaxyl-M and $20 \%$ tebuconazole before planting. Three seeds were then planted at a depth of $0.03 \mathrm{~m}$ and spacing of $0.4 \mathrm{~m}$ to obtain five plants per row and a total of 20 plants per sub-plot. The emerged seedlings were thinned to one plant per hole at two weeks after planting. Weeding was also done at intervals of two weeks throughout the period of the experiment. The field was irrigated with $2500 \mathrm{~L}$ of water every $48 \mathrm{~h}$ throughout the period of the experiment to maintain normal plant growth.

\section{Data collection}

Growth indices such as plant height, number of leaves and primary branches were determined at harvest. Plant height was measured using a ruler by measuring from the base of the stem to the top of the main shoot. Number of leaves and primary branches per plant were manually counted; number of root nodules was also determined after carefully uprooting the plant at harvest. The harvested plants from each of the $2 \times 2 \mathrm{~m}$ plots were used for yield determination (pod and seed yield as well as harvest index). This was achieved by carefully detaching the matured pods from the root, the pods were air dried to $12 \%$ moisture according to Myklestad (2006). They were then weighed using Metler Toledo balance (precision $0.1 \mathrm{~g}$ ) and then converted to $\mathrm{kg}$ per ha. Seeds obtained from the shelled pods were treated in the same manner as for pods. Harvest index was determined by dividing the economic yield by the biological yield according to the following formula:

Harvest index $=$ Economic yield (seed yield) / Biological yield (seed yield + above ground weight).

\section{Post-harvest soil nutrients determination}

Total nitrogen was determined by micro Kjedhal method according to Jones et al. (1991). Phosphorus was determined by spectrophotometric method following a serial dilution of an already digested soil sample (Murphy, Riley 1962). Sulphur was determined by turbidometry method following the digestion of $2 \mathrm{~g}$ of the soil sample with a nitric-perchloric tenary acid mixture according to Chandry and Confield (1966). Potassium, calcium, magnesium, manganese, iron, copper and zinc were measured by atomic absorption following a wet digestion of $1 \mathrm{~g}$ of the soil sample (Halon, De-Vore 1989). Boron was determined by azomethine-H method according to Patrovsky (1963), as adopted by Wolf (1974).

Table 1. Chemical properties of rice straw used in the study

\begin{tabular}{lc} 
Constituent (unit) & Value \\
Organic carbon (\%) & 1.87 \\
\hline Organic matter (\%) & 3.22 \\
\hline Sulphur $\left(\mathrm{mg} \mathrm{kg}^{-1}\right)$ & 390.4 \\
Phosphorus $\left(\mathrm{mg} \mathrm{kg}^{-1}\right)$ & 1170 \\
\hline Iron $\left(\mathrm{mg} \mathrm{kg}^{-1}\right)$ & 500.3 \\
\hline Nitrogen $(\%)$ & 1.05 \\
\hline Potassium (\%) & 1.50 \\
\hline Calcium $\left(\mathrm{mg} \mathrm{kg}^{-1}\right)$ & 470.3 \\
\hline Magnesium $\left(\mathrm{mg} \mathrm{kg}^{-1}\right)$ & 320.0 \\
\hline Copper $\left(\mathrm{mg} \mathrm{kg}^{-1}\right)$ & 19.3 \\
\hline Zinc $\left(\mathrm{mg} \mathrm{kg}^{-1}\right)$ & 330.5 \\
\hline Manganese $\left(\mathrm{mg} \mathrm{kg}^{-1}\right)$ & 115.6 \\
\hline Boron $\left(\mathrm{mg} \mathrm{kg}^{-1}\right)$ & 4.00
\end{tabular}




\section{Data analysis}

Data were analysed using the Analysis of Variance of Statistical Package for Social Science (SPSS) software version 20.0. Post-hoc test was conducted using the Duncan Multiple Range Test at 5\% level of probability for means separation.

\section{Results}

\section{Mineral analysis of rice straw}

The mineral composition of rice straw before application as soil amendment is shown in Table 1. The organic carbon concentration $(1.87 \%)$ was moderate. Straw was high in organic matter content $(3.22 \%)$, rich in phosphorus, calcium, magnesium and sulphur (1170, 470, 320 and $390 \mathrm{mg} \mathrm{kg}$, respectively), as well as iron and zinc (500 and $3301 \mathrm{mg} \mathrm{kg}^{-1}$, respectively). Other mineral elements such as boron, potassium, manganese copper and sodium had relatively low concentrations $\left(4.0,1.5,115 \mathrm{mg} \mathrm{kg}^{-1}\right.$, respectively).

\section{Pre-planting soil analysis}

Data on analysed soil physico-chemical properties before application of rice straw are presented in Table 2. The textural class of the top soil surface of the experimental field was sandy-loam; $\mathrm{pH}$ was 7.5. The soil had high levels of organic matter, exchangeable calcium and sodium with respective values of $5.18 \%, 0.05 \mathrm{cmol} \mathrm{kg}^{-1}$ and $1.22 \mathrm{cmol} \mathrm{kg}^{-}$ ${ }^{1}$; and moderate levels of available nitrogen $(0.25 \%)$. It was low in available phosphorus (4.12 $\left.\mathrm{mg} \mathrm{kg}^{-1}\right)$, exchangeable magnesium and potassium (1.64 and $0.94 \mathrm{cmol} \mathrm{kg}^{-1}$, respectively) and had low cation exchange capacity (6.55).

\section{Growth response and root nodules}

Growth characters considered were significantly $(p<0.05)$ affected by ground and unground rice straw treatment (Table 3). The control treatment had significantly lower plant height, number of leaves and number of branches when compared to plots treated with ground and unground rice straw. Ground rice straw at $2500 \mathrm{~kg} \mathrm{ha}^{-1}$ treatment resulted
Table 2. Soil physical and chemical properties

\begin{tabular}{|c|c|}
\hline Property (unit) & Value \\
\hline Silt (\%) & 6.00 \\
\hline Clay (\%) & 8.48 \\
\hline Sand (\%) & 85.52 \\
\hline Textural class & Loamy-sand \\
\hline $\mathrm{pH}_{\mathrm{H} 20}$ & 7.50 \\
\hline $\mathrm{pH}_{\mathrm{KCl}}$ & 7.00 \\
\hline Total acidity $\left(\mathrm{cmol} \mathrm{kg}^{-1}\right)$ & 2.70 \\
\hline Organic carbon (\%) & 2.34 \\
\hline Organic matter (\%) & 5.18 \\
\hline Total Kjedhal nitrogen & 0.20 \\
\hline Available phosphate & 4.12 \\
\hline Base saturation (\%) & 62.00 \\
\hline Cation exchange capacity & 6.55 \\
\hline $\mathrm{Ca}\left(\mathrm{cmol} \mathrm{kg}^{-1}\right)$ & 0.05 \\
\hline $\mathrm{Mg}^{2+}\left(\mathrm{cmol} \mathrm{kg}^{-1}\right)$ & 1.64 \\
\hline $\mathrm{K}^{+}\left(\mathrm{cmol} \mathrm{kg}^{-1}\right)$ & 0.94 \\
\hline $\mathrm{Na}^{+}\left(\mathrm{cmol} \mathrm{kg}^{-1}\right)$ & 1.22 \\
\hline
\end{tabular}

in significantly higher plant height, number of leaves and branches, when compared to those of unground rice straw. The highest application rate $\left(5000 \mathrm{~kg} \mathrm{ha}^{-1}\right)$ in both ground and unground rice straw resulted in the lowest growth attribute levels (Table 3). Root nodule count showed similar effects as those of growth parameters. However, unground rice straw at 2500 and $3750 \mathrm{~kg} \mathrm{ha}^{-1}$ resulted in significantly higher number of root nodules than other application rates (Table 3). Root nodule number was significantly lower at the highest application rate $\left(5000 \mathrm{~kg} \mathrm{ha}^{-1}\right)$ when compared to other treatments (Table 3).

\section{Effect of rice straw on yield of peanut at harvest}

Pod and seed yield were significantly affected by application of ground and unground rice straw (Table 4). Low application rates (1250 and $2500 \mathrm{~kg} \mathrm{ha}^{-1}$ ) produced significantly higher pod and seed yield for both ground and unground rice straw treatments. Pod and seed yield

Table 3. Yield parameters of groundnut. Values represent means \pm standard error, $(n=4)$. Superscript with same letters are not significantly different at $p<0.05$

\begin{tabular}{|lccccc} 
& $\begin{array}{l}\text { Treatments }\left(\mathbf{k g ~ h a}^{-1}\right) \\
\text { Control }\end{array}$ Average number $^{\text {of leaves }}$ & $\begin{array}{c}\text { Average number } \\
\text { of branches }\end{array}$ & $\begin{array}{c}\text { Average plant } \\
\text { height }(\mathbf{c m})\end{array}$ & $\begin{array}{c}\text { Average number } \\
\text { of root nodules }\end{array}$ \\
\hline Ground rice straw & 0 & $78.50 \pm 2.50^{\mathrm{g}}$ & $44.00 \pm 0.71^{\mathrm{f}}$ & $9.65 \pm 0.43^{\mathrm{g}}$ & $84.33 \pm 0.88^{\mathrm{e}}$ \\
\hline & 1250 & $163.50 \pm 4.27^{\mathrm{c}}$ & $81.75 \pm 2.14^{\mathrm{c}}$ & $12.50 \pm 0.24^{\mathrm{d}}$ & $83.00 \pm 1.76^{\mathrm{e}}$ \\
\hline Unground rice straw & 2500 & $235.70 \pm 3.38^{\mathrm{b}}$ & $118.00 \pm 1.77^{\mathrm{b}}$ & $16.12 \pm 0.43^{\mathrm{b}}$ & $92.67 \pm 1.16^{\mathrm{d}}$ \\
\hline & 3750 & $352.75 \pm 3.12^{\mathrm{a}}$ & $176.50 \pm 1.55^{\mathrm{a}}$ & $21.03 \pm 0.56^{\mathrm{a}}$ & $103.33 \pm 2.19^{\mathrm{c}}$ \\
\hline & 5000 & $133.75 \pm 3.11^{\mathrm{d}}$ & $66.75 \pm 1.54^{\mathrm{d}}$ & $10.58 \pm 0.28^{\mathrm{f}}$ & $37.33 \pm 2.65^{\mathrm{g}}$ \\
\hline & 1250 & $88.00 \pm 1.41^{\mathrm{f}}$ & $39.25 \pm 1.25^{\mathrm{g}}$ & $13.70 \pm 0.29^{\mathrm{e}}$ & $104.33 \pm 2.91^{\mathrm{c}}$ \\
\hline & 2500 & $162.50 \pm 1.89^{\mathrm{c}}$ & $57.25 \pm 1.10^{\mathrm{e}}$ & $14.70 \pm 0.25^{\mathrm{c}}$ & $146.67 \pm 1.76^{\mathrm{a}}$ \\
\hline & 3750 & $239.25 \pm 1.88^{\mathrm{b}}$ & $119.50 \pm 1.04^{\mathrm{b}}$ & $14.70 \pm 0.25^{\mathrm{c}}$ & $112.00 \pm 3.76^{\mathrm{b}}$ \\
\hline
\end{tabular}


Table 4. Yield parameters of groundnut. Values represent means \pm standard error, $n=4$. Superscript with same letters are not significantly different at $p<0.05$

\begin{tabular}{lcccc} 
& Treatments $\left(\mathbf{k g ~ h a}^{-1}\right)$ & Seed yield $\left(\mathbf{k g ~ h a}^{-1}\right)$ & Pod yield $\left(\mathbf{k g ~ h a}^{-1}\right)$ & Harvest index \\
Control & 0 & $650.50 \pm 73.16^{\mathrm{d}}$ & $1186.26 \pm 8.82^{\mathrm{e}}$ & $0.94 \pm 0.01^{\mathrm{a}}$ \\
Ground rice straw & 1250 & $1278.20 \pm 15.38^{\mathrm{a}}$ & $2133.30 \pm 18.56^{\mathrm{a}}$ & $0.95 \pm 0.00^{\mathrm{a}}$ \\
& 2500 & $976.17 \pm 35.10^{\mathrm{b}}$ & $2076.10 \pm 70.27^{\mathrm{a}}$ & $0.95 \pm 0.01^{\mathrm{a}}$ \\
\hline Unground rice straw & 3750 & $851.50 \pm 27.51^{\mathrm{c}}$ & $1083.30 \pm 31.79^{\mathrm{e}}$ & $0.94 \pm 0.00^{\mathrm{a}}$ \\
& 5000 & $488.33 \pm 6.01^{\mathrm{f}}$ & $1570.00 \pm 5.77^{\mathrm{b}}$ & $0.90 \pm 0.00^{\mathrm{b}}$ \\
& 1250 & $657.67 \pm 29.55^{\mathrm{d}}$ & $1196.00 \pm 8.82^{\mathrm{c}}$ & $0.95 \pm 0.00^{\mathrm{a}}$ \\
& 2500 & $820.00 \pm 12.00^{\mathrm{c}}$ & $1820.00 \pm 25.16^{\mathrm{b}}$ & $0.94 \pm 0.00^{\mathrm{a}}$ \\
& 3750 & $590.00 \pm 7.63^{\mathrm{e}}$ & $1350.00 \pm 65.57^{\mathrm{d}}$ & $0.95 \pm 0.00^{\mathrm{a}}$ \\
\hline
\end{tabular}

decreased with increase in the application rate of rice straw. Significantly lower pod and seed yield were recorded at the higher application rates, compared to other rates studied as well as the control (Table 4). Harvest index was significantly lower at higher application rates in both unground and ground rice straw, as it affected yield (Table 4). At each application rate, effect of ground and unground rice straw did not differ significantly and to that of the control (Table 4).

\section{Effect of rice straw on post-harvest soil $\mathrm{pH}$, organic matter and organic carbon}

Ground and unground rice straw application at $5000 \mathrm{~kg} \mathrm{ha}^{-1}$ significantly increased soil $\mathrm{pH}$ while all other application rates significantly decreased soil $\mathrm{pH}(p<0.05)$. Soil organic matter concentration was significantly increased by 1250 and $2500 \mathrm{~kg} \mathrm{ha}^{-1}$ ground and unground rice straw application rate, other application rates significantly decreased organic matter concentration $(p<0.05)$. Rice straw had no significant effect on soil organic carbon concentration (Table 5).

\section{Effect of rice straw on post-harvest soil macro nutrients}

Soil macronutrient concentrations in relation to rice straw application are shown in Table 6. All application rates significantly increased post-harvest soil nitrogen and phosphorus concentration when compared to the control. However, only 3750 and $5000 \mathrm{~kg} \mathrm{ha}^{-1}$ ground and unground rice straw application resulted in significantly higher postharvest soil potassium concentration. In contrast, 1250 and $2500 \mathrm{~kg} \mathrm{ha}^{-1}$ unground as well as $2500 \mathrm{~kg} \mathrm{ha}^{-1}$ ground rice straw application rate significantly decreased soil potassium concentration. In both rice straw treatment forms, application rates at $5000 \mathrm{~kg} \mathrm{ha}^{-1}$ significantly increased soil calcium and magnesium concentration over all other rates, except those grown in ground and unground rice straw at $3750 \mathrm{~kg} \mathrm{ha}^{-1}$ application rate where no significant effect was seed (Table 6). Application rates of 1250 and $2500 \mathrm{~kg} \mathrm{ha}^{-1}$ ground and unground rice straw significantly increased post-harvest soil sulphur concentration while 3750 and $5000 \mathrm{~kg} \mathrm{ha}^{-1}$ ground and unground rice straw application rates reduced post-harvest soil sulphur concentration (Table 6).

\section{Effect of rice straw on post-harvest soil micronutrients}

Post-harvest soil microelement concentrations in relation to ground and unground rice straw treatment are presented in Table 7. Elements such as iron, manganese, copper and zinc had significantly higher concentrations in plants grown in substrate treated with ground rice straw at 1250 and 2500 $\mathrm{kg} \mathrm{ha}^{-1}$ application rate when compared to those of same rates in unground rice straw plots. The concentration of

Table 5. Post-harvest soil $\mathrm{pH}$, organic carbon and organic matter. Values represent means \pm standard error, $n=4$. Superscript with same letters are not significantly different at $p<0.05$

\begin{tabular}{lcccc} 
& Treatments $\left(\mathbf{k g ~ h a}^{-1}\right)$ & pH & Organic carbon (\%) & Organic matter (\%) \\
Control & 0 & $7.40 \pm 0.36^{\mathrm{b}}$ & $1.56 \pm 0.00^{\mathrm{a}}$ & $5.20 \pm 0.01^{\mathrm{c}}$ \\
Ground rice straw & 1250 & $6.30 \pm 0.38^{\mathrm{e}}$ & $1.48 \pm 0.00^{\mathrm{a}}$ & $5.81 \pm 0.00^{\mathrm{b}}$ \\
& 2500 & $6.20 \pm 0.10^{\mathrm{d}}$ & $1.58 \pm 0.01^{\mathrm{a}}$ & $6.01 \pm 0.01^{\mathrm{a}}$ \\
\hline Unground rice straw & 3750 & $7.10 \pm 0.51^{\mathrm{c}}$ & $1.51 \pm 0.00^{\mathrm{a}}$ & $5.08 \pm 0.00^{\mathrm{d}}$ \\
& 5000 & $7.70 \pm 0.01^{\mathrm{a}}$ & $1.56 \pm 0.00^{\mathrm{a}}$ & $4.88 \pm 0.00^{\mathrm{d}}$ \\
\hline & 1250 & $6.50 \pm 0.18^{\mathrm{d}}$ & $1.51 \pm 0.00^{\mathrm{a}}$ & $5.71 \pm 0.00^{\mathrm{b}}$ \\
\hline & 2500 & $6.30 \pm 0.10^{\mathrm{e}}$ & $1.61 \pm 0.01^{\mathrm{a}}$ & $5.98 \pm 0.01^{\mathrm{a}}$ \\
\hline & 3750 & $7.10 \pm 0.21^{\mathrm{c}}$ & $1.56 \pm 0.00^{\mathrm{a}}$ & $4.98 \pm 0.00^{\mathrm{e}}$ \\
\hline
\end{tabular}


Table 6. Post-harvest soil macro nutrient concentration (\%). Values represent means \pm standard error, $n=4$. Superscript with same letters are not significantly different at $p<0.05$

\begin{tabular}{lccccccc} 
& $\begin{array}{c}\text { Treatments } \\
\left(\mathbf{k g ~ h a}^{-1}\right)\end{array}$ & Nitrogen & Phosphorus & Potassium & Calcium & Magnesium & Sulphur \\
\hline Control & 0 & $0.16 \pm 0.01^{\mathrm{d}}$ & $3.90 \pm 0.02^{\mathrm{g}}$ & $187.00 \pm 1.45^{\mathrm{e}}$ & $6800.0 \pm 11.54^{\mathrm{c}}$ & $246.67 \pm 4.88^{\mathrm{c}}$ & $10.87 \pm 0.01^{\mathrm{e}}$ \\
\hline Ground rice straw & 1250 & $0.25 \pm 0.08 \mathrm{~b}^{\mathrm{c}}$ & $4.31 \pm 0.01^{\mathrm{c}}$ & $188.27 \pm 5.21^{\mathrm{c}}$ & $4900.0 \pm 28.3^{\mathrm{f}}$ & $205.00 \pm 3.88^{\mathrm{f}}$ & $12.31 \pm 0.01^{\mathrm{c}}$ \\
& 2500 & $0.24 \pm 0.03^{\mathrm{c}}$ & $4.20 \pm 0.00^{\mathrm{e}}$ & $143.17 \pm 1.33^{\mathrm{g}}$ & $3698.0 \pm 1.7^{\mathrm{g}}$ & $220.33 \pm 0.33^{\mathrm{d}}$ & $11.67 \pm 0.01^{\mathrm{d}}$ \\
& 3750 & $0.26 \pm 0.03^{\mathrm{ab}}$ & $4.45 \pm 0.02^{\mathrm{b}}$ & $272.00 \pm 4.04^{\mathrm{c}}$ & $6768.0 \pm 20.4^{\mathrm{c}}$ & $252.33 \pm 0.33^{\mathrm{c}}$ & $6.34 \pm 0.02^{\mathrm{h}}$ \\
\hline Unground rice straw & 5000 & $0.28 \pm 0.02^{\mathrm{a}}$ & $4.55 \pm 0.04^{\mathrm{a}}$ & $348.83 \pm 3.76^{\mathrm{b}}$ & $7333.0 \pm 27.6^{\mathrm{b}}$ & $269.00 \pm 2.08^{\mathrm{b}}$ & $5.97 \pm 0.08^{\mathrm{i}}$ \\
\hline & 1250 & $0.24 \pm 0.01^{\mathrm{c}}$ & $3.94 \pm 0.02^{\mathrm{f}}$ & $170.00 \pm 5.20^{\mathrm{f}}$ & $6583.3 \pm 24.1^{\mathrm{d}}$ & $215.00 \pm 1.00^{\mathrm{e}}$ & $15.54 \pm 0.32^{\mathrm{b}}$ \\
\hline & 2500 & $0.26 \pm 0.01^{\mathrm{b}}$ & $4.23 \pm 0.01^{\mathrm{d}}$ & $143.00 \pm 1.26^{\mathrm{g}}$ & $6386.0 \pm 13.3^{\mathrm{e}}$ & $207.33 \pm 1.45^{\mathrm{f}}$ & $16.67 \pm 0.08^{\mathrm{a}}$ \\
\hline & 3750 & $0.28 \pm 0.00^{\mathrm{a}}$ & $4.30 \pm 0.01^{\mathrm{c}}$ & $203.67 \pm 2.03^{\mathrm{d}}$ & $6771.0 \pm 25.9^{\mathrm{c}}$ & $251.33 \pm 1.45^{\mathrm{c}}$ & $7.69 \pm 0.01^{\mathrm{g}}$ \\
\hline & 5000 & $0.29 \pm 0.00^{\mathrm{a}}$ & $4.41 \pm 0.02^{\mathrm{b}}$ & $390.67 \pm 0.33^{\mathrm{a}}$ & $14112.0 \pm 19.6^{\mathrm{a}}$ & $615.00 \pm 2.89^{\mathrm{a}}$ & $8.67 \pm 0.01^{\mathrm{f}}$ \\
\hline
\end{tabular}

boron was higher at lower application rate of unground rice straw, when compared to same rate of ground rice straw (Table 7). Molybdenum concentration in post-harvest soil was found to increase with increasing application rate of both ground and unground rice straw. Highest values of this element were recorded with application rate at $5000 \mathrm{~kg}$ $\mathrm{ha}^{-1}$ in both ground and unground rice straw (Table 7).

\section{Discussion}

Rice straw had $\mathrm{C} / \mathrm{N}$ ratio of $1: 1$, which is a clearer indication that the material can decompose rapidly. Its high organic matter and low organic carbon concentration were adequate for the growth and development of groundnut. Similar results were reported by Olayinka and Etejere (2016) in their studies of effect of weed control methods on growth and yield of two varieties of groundnut.

Soil physicochemical character before application of rice straw indicates that the soil is slightly alkaline, which might not support the growth of groundnut due to deficiency of some elements such as manganese, iron and zinc (Rich 1956). Manganese deficiency was evident in plots with $\mathrm{pH}$ levels near 6.8 and not in plots with $\mathrm{pH}$ levels of 5.2 or 6.0 on Pelham sand in Georgia (Parker, Walker 1967). The high soil calcium concentrations obtained in this study could result in soil salinity and induce iron and zinc deficiency. Yield response to iron application in Israel was related to high content of calcium carbonate in the soil (Lachover et al. 1970). In a survey of 35 peanut fields in Cyprus it was observed that plants became chlorotic when content of calcium carbonate was greater than 20 to $25 \%$, and iron content was less than $2500 \mathrm{~kg} \mathrm{ha}^{-1}$ (Papastylianou 1989). A critical soil zinc level $1.0 \mathrm{mg} \mathrm{kg}^{-1}$ when calcium concentration is greater than $400 \mathrm{mg} \mathrm{kg}^{-1}$ has been suggested (Rhoald et al. 1989). Other soil parameters such as organic matter, organic carbon, and textural class were within the normal range necessary for optimum growth of groundnut.

The observed general increase in vegetative growth, particularly at low application rates of ground and unground rice straw might be associated with nitrogen, phosphorus and potassium levels in the soil, facilitated by faster rate of decomposition of rice straw and conversion into an assimilable form for plant uptake. The results obtained in the present work are in agreement with the study of Kannan and Saravanan (2006) on groundnut crop growth benefits and soil quality from use of animal manure as fertilizer. The decrease in the growth traits at $5000 \mathrm{~kg} \mathrm{ha}^{-1}$ application of ground and unground rice straw might be due to the high dose of rice straw, which apparently takes

Table 7. Post-harvest soil micro nutrient concentration $\left(\mathrm{mg} \mathrm{kg}^{-1}\right)$. Values represent means \pm standard error, $n=4$. Superscript with same letters are not significantly different at $p<0.05$

\begin{tabular}{lccccccc} 
& $\begin{array}{c}\text { Treatments } \\
\left(\mathbf{k g ~ h a}^{-1}\right)\end{array}$ & Iron & Manganese & Copper & Boron & Molybdenum & Zinc \\
& 0 & $431.33 \pm 21.71^{\mathrm{d}}$ & $60.66 \pm 0.33^{\mathrm{d}}$ & $1.31 \pm 0.02^{\mathrm{e}}$ & $2.45 \pm 0.01^{\mathrm{e}}$ & $2.37 \pm 0.02^{\mathrm{c}}$ & $1.54 \pm 0.06^{\mathrm{e}}$ \\
\hline Control & 1250 & $822.67 \pm 1.33^{\mathrm{a}}$ & $80.33 \pm 1.45^{\mathrm{a}}$ & $1.90 \pm 0.01^{\mathrm{a}}$ & $3.44 \pm 0.01^{\mathrm{c}}$ & $1.27 \pm 0.06^{\mathrm{e}}$ & $4.59 \pm 0.03^{\mathrm{a}}$ \\
\hline Ground rice straw & 2500 & $740.33 \pm 4.33^{\mathrm{b}}$ & $76.00 \pm 1.73^{\mathrm{b}}$ & $1.85 \pm 0.01^{\mathrm{b}}$ & $2.89 \pm 0.02^{\mathrm{d}}$ & $1.13 \pm 0.01^{\mathrm{f}}$ & $3.07 \pm 0.11^{\mathrm{b}}$ \\
& 3750 & $430.00 \pm 3.46^{\mathrm{d}}$ & $55.33 \pm 0.73^{\mathrm{e}}$ & $1.30 \pm 0.03^{\mathrm{e}}$ & $2.32 \pm 0.13^{\mathrm{g}}$ & $3.74 \pm 0.09^{\mathrm{b}}$ & $1.51 \pm 0.03^{\mathrm{e}}$ \\
\hline & 5000 & $365.00 \pm 0.57^{\mathrm{e}}$ & $46.00 \pm 0.58^{\mathrm{e}}$ & $1.16 \pm 0.01^{\mathrm{g}}$ & $2.14 \pm 0.01^{\mathrm{d}}$ & $3.71 \pm 0.11^{\mathrm{b}}$ & $1.11 \pm 0.01^{\mathrm{f}}$ \\
\hline Unground rice straw & 1250 & $528.00 \pm 1.45^{\mathrm{c}}$ & $80.33 \pm 1.05^{\mathrm{a}}$ & $1.76 \pm 0.00^{\mathrm{c}}$ & $4.11 \pm 0.00^{\mathrm{a}}$ & $2.16 \pm 0.04^{\mathrm{d}}$ & $2.50 \pm 0.09^{\mathrm{c}}$ \\
& 2500 & $741.33 \pm 1.33^{\mathrm{b}}$ & $74.00 \pm 1.70^{\mathrm{c}}$ & $1.70 \pm 0.00^{\mathrm{d}}$ & $3.65 \pm 0.01^{\mathrm{b}}$ & $2.14 \pm 0.03^{\mathrm{d}}$ & $1.83 \pm 0.02^{\mathrm{d}}$ \\
\hline & 3750 & $435.00 \pm 2.89^{\mathrm{d}}$ & $53.33 \pm 0.73^{\mathrm{f}}$ & $1.25 \pm 0.00^{\mathrm{f}}$ & $2.40 \pm 0.05^{\mathrm{e}}$ & $3.80 \pm 0.07^{\mathrm{b}}$ & $1.52 \pm 0.01^{\mathrm{e}}$ \\
\hline & 5000 & $335.00 \pm 1.16^{\mathrm{f}}$ & $46.00 \pm 0.57^{\mathrm{g}}$ & $0.93 \pm 0.01^{\mathrm{h}}$ & $1.58 \pm 0.01^{\mathrm{h}}$ & $4.25 \pm 0.02^{\mathrm{a}}$ & $0.97 \pm 0.03^{\mathrm{f}}$ \\
\hline
\end{tabular}


more time to decompose for release of nutrients. These findings were in agreement with Edna et al. (2000) who reported 25k $\mathrm{g} \mathrm{ha}^{-1}$ NPK fertilizer gave optimum yield in groundnut, with lower yield at higher doses. Similar results were also obtained by Bhatol et al. (1994) in their studies of uptake of nutrients in groundnut.

The increased pod and seed yield of groundnut plots treated with ground rice straw might be due to improved soil condition coupled with large surface area of straw at low dosage which promotes faster decay and release of nutrients (Jagdev, Songh 2000). The decrease in pod and seed yield at higher doses might be due to the large volume of straw in which little water was retained, resulting in slower decay of the straw and release of nutrient needed for pod growth and seed filling. This result is in agreement with the study of Suryanarayana (1991) on the effect of amendment of red sandy loam.

The decline of $\mathrm{pH}$ after 1250 and $2500 \mathrm{~kg} \mathrm{ha}^{-1}$ treatment as well as increase of $\mathrm{pH}$ observed at 3750 and $5000 \mathrm{~kg}$ $\mathrm{ha}^{-1}$ treatment can be due to accumulation of organic matter via accelerated straw mineralization at optimum concentration. Soil acidification under clover pastures had been attributed to the accumulation of organic matter in the soils (Williams 1980).

The increase in N-P-K content of soil at lower application rates of ground and unground rice straw is obviously due to increase in the rate of decomposition. A significant increase in organic carbon, available nitrogen and phosphorus content of soil with application of organic manure was reported previously (Ismail et al. 1998). Lower calcium and magnesium concentration in 1250 and 2500 $\mathrm{kg} \mathrm{ha}^{-1}$ treatments of ground and unground rice straw may be linked to drop in the $\mathrm{pH}$ of the soil, as reported by Das et al. (1992) in their studies on mineral nutrients of maize and groundnut as influenced by phosphate-enriched manure on acid soils.

The increased post-harvest soil iron, manganese, copper, boron and zinc concentration at 1250 and $2500 \mathrm{~kg} \mathrm{ha}^{-1}$ ground and unground rice straw application rates might be due to the chelating actions of organic compounds released during decomposition of rice straw, which prevent fixation, oxidation, precipitation and leaching. A similar situation was observed in studies on effect of fertilizers of organic and inorganic sources on micronutrient uptake in maize (Walia, Kler 2010). The decrease of the mineral element concentration at 3750 and $5000 \mathrm{~kg} \mathrm{ha}^{-1}$ ground and unground rice straw application rates might be linked to high soil $\mathrm{pH}$ resulting from reduced decomposition rate of rice straw at such high application rates. Decrease of molybdenum concentration 1250 and $2500 \mathrm{~kg} \mathrm{~h}^{-1}$ and increase in 3750 and $5000 \mathrm{~kg} \mathrm{ha}^{-1}$ ground and unground rice straw treatments might be due to availability of micronutrients, as explained earlier. Similar results have been reported by Kumar et al. (2000) in their studies on the effect of manure and inorganic fertilizer on grain yield and changes in soil micronutrient concentration in a rice-wheat system.

In conclusion, this study showed that lower application rates (1250 to $2500 \mathrm{~kg} \mathrm{ha}^{-1}$ ) of ground and unground rice straw are optimum for use as soil amendment in groundnut production, as these rate significantly enhanced pod and seed yield as well as some post-harvest soil nutrient concentration.

\section{References}

Abdelhamid M,T., Horiuch T., Oba S. 2005. Composting of rice straw with oil seed rape cake and poultry manure and its effect on faba been (Vicia faba L.) grown and soil properties. Bioresour. Technol. 93:183-189.

Anderson J.M., Ingram S.J. (eds) 1993. Tropical Soil Biology and Fertility: A Handbook of Methods. Oxford University Press, Oxford.

Basel N., Sami M. 2014. Effect of organic and inorganic fertilizers application on soil and cucumber (Cucumis sativa L.) plant productivity. Int. J. Agric. For. 4: 166-170.

Bhatol N.A., Patel A.S., Payaya R.P. 1994. Effect of nitrogen, phosphorus and potassium on growth yield and uptake of nutrients by groundnut. J. Agric. Sci. 28: 209-213.

Binod P., Sindhu R., Singhania R.R., Vikram S., Devi L., Nagalakshmi S., Kurien N., Sukumaran R.K., Pandey A. 2010. Bioethanol production from rice straw: an overview. Bioresour. Technol. 101: 4767-4774.

Chitdeshwari T., Poongathai S. 2003. Yield of groundnut and nutrient uptake as influenced by Zn, B, and S. Agric. Sci. Digest 23:263-265.

Das M., Singh B.P., Ram M., Prasad R.N. 1992. Mineral nutrient of maize and groundnut as influenced by $P$ enriched manures on acid alfisols. J. Indian Soc. Soil Sci. 40: 580-583.

Edna A., Doddamani M.B., Mummigatti U.V., Chetti M.B. 2000. Canopy characteristic and its relation with yield in groundnut. Haryana J. Agron. 16: 7-10.

El-Gammal M.I., Shakour A.A. 2001. Emission of pollutants from harvest and burning of rice straw in Egypt villages (North East of Nile Delta). J. Union Arab. Biol. 15: 191-206.

El-Naim A.M., Eldouma M.A., Ibrahim E.A., Zaied M.A. 2011. Infiuence of plant spacing and growth and yield of peanut (Arachis hypogaea L) in rain fed of Sudan. Adv. Life Sci. 1: $45-48$.

Ismail S., Malewar G.U., Rege V.S., Yelvikar N.V. 1998. Influence of FYM and gypsum on soil properties and yield of groundnut grown in vertisols. Agropedology 8: 73-75.

Jagdev S., Singh K.P. 2000. Effect of Azotobacter, FYM and fertility levels on yield, nitrogen recovery and use efficiency in spring sunflower. Haryana J. Agron. 16: 57-60.

Jones J.B., B. Wolf B., Mills H.A. 1991. Preparation and analysis. In: Plant Analysis Handbook. A Practical Sampling, Preparation, Analysis, and Interpretation Guide. Micro-Macro Publishing, Athens, Georgia, pp. 23-26.

Kannan P., Saravanan A. 2006. Crop growth benefits and soil quality impact of using animal manure as fertilizer. Trans. ASAE 5: 339-348.

Kumar R., Singh G., Bhandari A.L., Walia S.S. 2000. Effect of manure and fertilizer on grain yield and changes in soil micronutrient under rice wheat system. Environ. Ecol. 18: 634-638. 
Lachover D., Fichman M., Har-Tzook A. 1970. The use of iron chelates to correct chlorosis in peanuts under field conditions. Oleagineux 25: 85-88.

Lemieux P.M., Lutes C.C., Santoianni D.A. 2004. Emissions of organic air toxics from open burning: A comprehensive review. Prog. Energy Combustion. Sci. 30: 1-32.

Murphy J., Riley J.P. 1962. A modified single solution or the determination of phosphate in natural waters. Anal. Chim. Acta 27: 31-36.

Munda G.C., Patel D.P., Islam M. 2004. Effect of macro and micronutrients on growth and yield of groundnut. Ann. Plant Physiol. 18: 9-12.

Mykleastad O. 2006. Physical aspect of the drying of groundnut. J. Sc. Food Agric. 16: 658-667.

Nelson D.W., Somners L.E. 1982. Total carbon, organic carbon and organic matter. In Page A.L. (ed) Methods of Soil Analysis. Part 2. Chemical and Microbiological Properties. ASA, SSSA, Madison, 539-594

Okalebo J.R., Gathua K.W., Woomer P.L. 2002. Laboratory Methods of Soil and Plant Analysis. Nairobi, Kenya.

Olayinka B.U., Etejere E.O. 2016. Weed control methods affect growth, yield and economic returns in groundnut. Ann. West Univ. Timisoara ser. Biol. 19: 17-24.

Patrovsky V. 1963. Photometric determination of boron in aqeous medium ristyphthalm violet. Talanta 10: 175-179.

Papastylianou I. 1989. Effect of selected soil factors on chlorosis of peanuts grown in calcareous soils in Cyprus. Plant Soil 117: 291-294.
Rich C.I. 1956. Manganese content of peanut leaves as related to soil factor. Soil Sci. 82: 353-363.

Rhoads F.M., Shokes S., Gorbet D.W. 1989. Response of two peanut cultivars to soil zinc levels. Univ. of Florida, Institute of Food and Agricultural Sciences, Research Report NF-89-2.

Suryanarayana R.R. 1991. Effect of soil amendments on the hardening of redsandy loams (Chalka soils) of Andhra Pradesh. Ann. Agric. Res. 12: 174-176.

Thorave D.S., Dhonde M.B. 2007. Morphological indices and yield attributes as influenced by integrated nutrient management in summer groundnut. Ann. Plant Physiol. 21: 186-188.

Veerahmani P., Subrahmaniyan K. 2011. Nutrient management for sustainable groundnut productivity in India - a review. Int. J. Eng. Sci. Technol. 3: 8138-8153.

Vinod K.B.C., Ghose R., Karmakar S. 2000. Effect of irrigation and fertilizer on yield, water- use efficiency and nutrient uptake of summer groundnut. Indian J. Agron. 45: 756-760.

Walia S.S., Kler D.S. 2010. Effect of organic and inorganic sources of nutrition on growth, macro and micronutrient uptake in maize under maize-wheat sequence. Indian J. Ecol. 37: 27-29.

Williams C.H. 1980. Soil acidification under clover pasture. Austr. J. Exp. Agric. Anim. Husb. 20: 56-7.

Wolf B. 1974. Improvement in azomethine H. method for the determination of boron. Comm. Soil Sci. Plant Anal. 5: 39-44.

Yukihiko M., Tomoaki M., Hiromi Y. 2005. Amount availability, and potential use of rice straw (agricultural resolve) biomoss as an energy resource in Japan. Biomass Bioen. 29: 347-354. 